M. Vokrri*

\title{
ASPECTS OF SAFETY AND HEALTH AT WORK IN THE CONTEXT OF EU AND KOSOVO
}

UDK 613.6:061.1EU](497.115)

RECEIVED: 2020-04-07

ACCEPTED: 2021-07-19

\author{
This work is licensed under a Creative \\ Commons Attribution 4.0 International License
}

SUMMARY: Occupational Safety and Health are the two key components of employee efficiency in their workplace, and at the same time guaranteeing them can directly impact employee wellbeing and productivity for employers and their earnings. Obviously, legal definition and their protection fall under the State domain, respectively Institutions that are authorized to supervise the implementation of legislation by the employers. Having in consideration the facts that reports obtained from the labor field, particularly those of "Occupational Safety and Health" reflect the continuous challenges of majority of employees, it is understandable why there is a need for adequate legal regulation in this field at national and international level, including international standards (ILO Conventions), as well as the Treaties - EU Directives referring to the relevant field. In this context, an attempt was to elaborate on the nature and importance of these two components in the international level as well as the reflection they have within national legislation specifically the case of Kosovo in relation to ILO Conventions and with EU law, with EC Framework Directive no. 89/391 of 12 June 1989. The reasons for such elaboration lie in the fact of our society's aspirations to be part of the European Union, and the development of adequate legislation in this field as well as compatible with EU law, particularly after signing the Stabilization and Association Agreement (SAA) between Kosovo and the European Union (EU), where practically Kosovo has taken the legal and contractual obligation to approximate national legislation with the EU Acquis. The challenges in implementing national legislation as well as the increasing number of deaths and injuries in the workplace will be the focus of this study. In this context methods for practical harmonization will be analyzed and studied, as well as recommendations on how to act in specific areas so that workers are guaranteed dignity and above all, safety and health at their workplace.

Ključne riječi: occupational safety and health, European law, Acquis Stabilization and Association Agreement (SAA) between Kosovo and EU, directives, labor inspectorate

\section{INTRODUCTION}

The need for sustainable and functional legislation is essential across entire areas of social life, but undoubtedly the areas by which the interests of the citizens and particularly employees is most important is that of work relationships as well as the processes that arise from such relations.

From this standpoint, the right to work and the rights at work play an important role in attaining

*Muhamet Vokrri, PhD, (muhamet.vokrri@uni-pr.edu), Professor Assistant, Law Faculty, Str. Agim Ramadani, 10000 Prishtinë, Albania. human safety. Based on the current concept, work should not only provide for well-being, but also about relationships and participation in society. The success that emerges from employment, is not then necessarily only that linked to status and income, but is bound up in the activity performed, the motivation for being active, and the potential rewards through enhancing the welfare of dependents (Beverly, 2008).

The substantive content of labor law has changed over the time. In the early years of the industrial revolution, it sought to protect the most 
vulnerable workers against physical and moral brutality, then to ensure that they worked in safe and salubrious conditions and ultimately to require that they be paid enough to meet "the normal needs of the average employee regarded as a human being living in a civilized community" (Arthurs, 2011). However, from the end of the $19^{\text {th }}$ century, and through much of $20^{\text {th }}$ century, labor law was largely focused on collective issues.

In this regard, the Conventions of International Labour Organization (ILO) (UN Special Agency) and EU Law, beside others, pay special importance to the safety and health of workers at work, as preventive measures and the protection of workers' rights, and is considered as an important factor for the well-being of their lives and society (the state) in general.

The ILO's primary goal is to promote opportunities for women and men to obtain decent and productive work in conditions of freedom, equity, security and dignity. In this formulation ${ }^{1}$ of decent work in the context of ILO action, the protection of workers against work-related sickness, disease and injury, as embodied in the Preamble to the Constitution of the ILO, is an essential element of security and continues to be a high priority for the ILO (ILO Report, 2003).

Occupational accidents and work-related diseases have a major impact on individuals and their families, not only in economic terms, but also in terms of their physical and emotional wellbeing in the short and long term. Furthermore, they can have major effects on enterprises, affecting productivity, leading to potential disruptions of production processes, hampering competitiveness and reputation on enterprises along supply chains, and impacting on economy and society more widely (ILO Office, 2019).

According to recent estimates released by the International Labor Organization (ILO), each year 2.78 million workers die from occupational accidents and work-related diseases (of which 2.4 million are disease-related) $)^{2}$ and an additional

\footnotetext{
${ }^{1}$ Accessible at: https://www.ilo.org/global/topics/safety-andhealth-at-work/resources-library/publications/WCMS_177455/lang-en/index.htm p. 3, accessed: 03.11.2020.

${ }^{2}$ Accessible at: https://www.ilo.org/safework/events/safeday/ WCMS_686645/lang--en/index.htm p. 1., accessed: 3.11.2020.
}

374 million workers suffer from non-fatal occupational accidents (ILO Office, 2019).

In addition to occupational injuries and recognized occupational diseases, work-related illnesses such as stress and psychological problems, are increasingly reported, which are very difficult to resolve and are present in all activities and types of work. Therefore, in contemporary conditions, greater attention will have to be paid to the risks and risk factors that are associated with the process of work organization, workers' psycho-physical abilities, and economic and social relationships.

Like all EU legislation, EU labor law and occupational safety and health rules are Treaty-based, which form an integral part of the Directives for EU Member States. Protecting the health and safety of workers has been one of the European Community's main concerns in its social policies since the revision of the 1986 Single European Act.

The carefulness to ensure a safe and healthy work environment for European Union (EU) employees has been the reason for the creation of specific structures in charge of this problem. It empowers the Council and the European Parliament to adopt the legislative basis in order to improve the working environment and to protect the health and safety of workers (Hennion, Le Bris, Del Sol, 2010).

A wide range of Community measures in the field of occupational safety and health have been adopted under Article 153 of the Treaty on the Functioning of the European Union. EU directives, which lay down minimum requirements and basic principles, such as the principle of risk prevention and assessment, and the responsibilities of employers and employees are legally binding and must be transposed into national law by Member States.

With the introduction of new technologies, content and work processes, changes in the structure of the workforce and the labor market, as well as new forms of employment and work organization, work and job openings are constantly changing. These changes may pose new risks and challenges to the safety and health of workers, therefore in 1996, in order to co-ordinate and maintain health and safety standards across 
Europe, the EU established the European Agency for Safety and Health at Work, which has its base in Bilbao, Spain (Reg. No. 2062/94).

This decentralized European Union Agency is responsible for collecting, analyzing and disseminating relevant information that can serve the needs of people involved in occupational safety and health.

From the constitutional point of view, Kosovo in its constitutional legal act (Constitution, 2008) reflects the areas of human rights protection and some of these rights are implied by the employment relationship.

More specifically, Article 22 [Direct Applicability of International Agreements and Instruments] states that "Human rights and freedoms guaranteed by international treaties and instruments, are guaranteed in the Constitution, and are directly applied in the Republic of Kosovo and have priority in case of conflict against legal provisions and other acts of public institutions". Further, Article 49 explicitly guarantees every citizen of Kosovo the "Right to Work and Exercise Profession".

Following the signing of the Stabilization and Association Agreement (SAA) with the $\mathrm{EU}^{3}$, Kosovo has assumed the legal obligation to approximate its national legislation with the Acquis and consequently also in the field of labor.

As the first contractual agreement between the two parties, the SAA represents a new phase of political relations between Kosovo and the EU. Furthermore, the SAA establishes the framework of Kosovo's relations with Member States and EU institutions for the implementation of the Stabilization and Association Process until full EU accession. In terms of scope, except for political issues and legal obligations (including those affecting the field of work) the SAA covers all areas of government.

Therefore, an assessment of the crucial EU Directives referring to this area will be undertaken, and of course an analysis of how well our natio-

\footnotetext{
${ }^{3}$ Accessible at: http://mei-ks.net/repository/docs/20171027102511_ kosovo-eu_saa_final_en.pdf, accessed: 26.3.2020.
}

nal legislation is in line with these acts (the Directive) will be carried out, as well as their practical implementation.

\section{EU LAW ON OCCUPATIONAL SAFETY AND HEALTH}

Labor was posited in the Treaty of Rome as one of the factors for which free movement was guaranteed, along with capital, goods and services (Bercusson, 2009). Furthermore, the European Social Charter of 1961 (revised in 1996), and the European Convention of Human Rights, also contain provisions regarding labour and social affairs.

The EU's competences generally follow the principles codified in the Community Charter of Fundamental Social Rights of Workers on 9 December 1989 (Bronstein, 2009), and than introduced in the "social charter" of the Treaty of Maastricht (known as the Treaty on European Union) signed on 7 February 1992. Later the Charter of Fundamental Rights of the European Union, signed by the members of the EU in Nice 2001, also included an important charter of the right workers ( $D i$ Federico, 2010).

Under the Treaty on the Functioning of the European Union (Art. 153, TFEU) the EU is able to use the ordinary legislation procedure on a list of labour law fields. The EU aims to promote social progress and to improve the living and working conditions of the peoples in Europe.

Upon entry into force of the Treaty of Lisbon the number of EU secondary legal acts was reduced from 15 to 5 types: Regulations, Directives, Decisions, Recommendations and Opinions. The names of the remaining types of EU legal acts were left unchanged.

More specificially Art. 288 of the TFEU provides for that in the future the same three types of binding legal instruments (Regulations, Directives and Decisions) will be available at three different levels of law-making: for legislation as such, for the adoption of delegated acts and for the adoption of implementing acts. Their position at one of these three levels will be indicated in the formal denomination of the EU legal act (De Witte et al. 2008). 
The framework Directive on the Introduction of Improvements in the Health Protection and safety at work is of central significance for the protection of employees at work in Europe. On the one hand, it contains rules in a general form for the equipment of the workplace and the work organization in the enterprise with the aim of avoiding accidents at work and preventing occupational health and risks (Lowisch, 2003).

European legislation in the field of occupational health and safety is systematically presented in two blocks, that of the Framework Directive, which contains all the provisions regarding the care to be shown in the field of occupational health and safety and the numerous specific Directives, which complement the general framework in order to consider specific protection needs (Hennion, Le Bris, Del Sol, 2010).

Framework Directive 89/391/EEC, commonly referred to as the "basic law", sets out common principles which are generally applicable and further specified by nineteen other individual directives, based on Article 16 (1) of the Framework Directive, whose overall aim is to ensure the health, safety and welfare of workers and to preserve the welfare and productivity of businesses. This means that the provisions of the Framework Directive always apply unless there are other more specific provisions (lex specialis). ${ }^{4}$

Article 7 of directive shows the importance on the obligations and responsibilities of the employer in relation to the employee. In this regard the employer is obliged to consistently adhere to the principles of risk prevention, risk assessment that cannot be avoided, by fighting the source of risks, preventing work from being monotonous and uniform as well as employer obligations that cover aspects related to the health and safety of employees.

The Article 13 of Directive emphasizes the following: "It shall be the responsibility of each worker to take care as far as possible of his own safety and health and that of other persons affected by his acts or commissions at work in accordance with his training and the instructions given

\footnotetext{
${ }^{4}$ Accessible at: https://oshwiki.eu/wiki/Workplace_minimum requirements_and_EU_OSH_legislation, accessed: 30.6.2018.
}

by his employer" in order to avoid accidents. The case law of the European Court of Justice is enriched in the relevant cases (ECJ C - 226/06)

Naturally, the effect of these obligations must be relativized, because their breach by the worker cannot in any way alleviate the responsibility of the employer, whereby the Directive (Article 5 paragraph 3) itself provides that "The workers' obligations in the field of safety and health at work shall not affect the principle of the responsibility of the employer"

It is important and has been addressed the Annex to Directive 89/391/EEC, which contains a list of seven areas, including workplaces, work equipment, personal protective equipment, work with display equipment, work with heavy weighs that can cause serious health hazards, temporary and mobile shipyards, fishing and agriculture, for which additional legislation had to be adopted.

In this regard, numerous Directives have been adopted to supplement the Framework Directive, which are referred to as "Special Directives" in accordance with Article 16 (1) of Directive 89/391/ EEC. Independent Directives of Framework Directives were added, as well as several inter-professional framework agreements based on social dialogue at European level. During the 1990s and in the period 2002-2006, a significant number of other Supplementary Directives have been issued which refer to occupational safety and health, including pregnant women and nursing mothers.

The Framework Directive - 89/391/EEC and the Supplementary Directives pay particular importance to protection for pregnant women workers. In this respect, Directive 92/85/EC of 19 October 1992 is about the implementation of measures designed to promote the continuous improvement of occupational safety and health for pregnant women workers, nursing or breast-feeding. In the spirit of the purpose of Convention no. 183 of the ILO, which was promulgated in 2000, the Directive mainly insists on the need to protect the psychological and biological state of employees at this stage of their lives and to protect rights related to a contract or employment relationship.

${ }^{5}$ Accessible at: https://eur-lex.europa.eu/legal-content/en/TXT/ PDF/?uri=uriserv\%3AOJ.C_.2008.183.01.0002.01.ENG, accessed: 20.5.2019. 
The Directive obliges Member States to grant pregnant workers a minimum of fourteen (14) weeks of uninterrupted maternity leave, which is taken at the discretion of the interested parties, before or immediately after birth. In this regard an important ECJ decision in the Kiiski case (C- $116 / 06)^{6}$ is relevant for reference, where the court states that the right to leave (maternity leave) is intended not to allow pregnant workers to be subject to "double overwork", that arises out of the exercise of a professional activity and that childcare during childbirth constituted a burden, equal to that of a professional activity.

It should also be noted that the fourteen (14) week of leave is the minimum possible. Thus, Directive $92 / 85 / E C$ is intended to set only a minimum standard for compulsory protection and provides a non-regression, which enables Member States to increase the level of protection provided by their legislation.

It must be acknowledged that the adverse consequences of occupational health due to pregnancy can cause stress and anxiety with potential pathogenic consequences, so measures should be taken to safeguard women to the best of their health and safety at work. This is also the aim of the consideration of the Fifteenth Directive, which sets out the detrimental effects that dismissal can have on the "physical and mental state of pregnant workers (Hennion, Le Bris, Del Sol, 2010).

This is also the reason that the main protection measure relates to the prohibition of dismissal from the beginning of pregnancy until the end of the maternity leave. Additionally, the importance of the protection to be given to pregnant women is set out in the Paquay decision of 11 October 2007 (ECJ C-460/06) ${ }^{7}$. In this decision, the court pointed out that the directive prohibits not only the notification of dismissal due to pregnancy and maternity leave, but also the preparation (seeking a substitute) during this time of a dismissal decision, which would be disclosed to the person concerned after the end of the period of protection.

\footnotetext{
${ }^{6}$ Accessible at: http://curia.europa.eu/juris/liste.jsf?num=C-116/06, accessed: 24.3.2020.

${ }^{7}$ Accessible at: http://curia.europa.eu/juris/showPdf.jsf;jsessionid=9 D05C5950F61AF9222CF23013EEFE793?text=\&docid=69846\&pagelnd ex $=0 \&$ doclang $=E N \&$ mode $=\mid \mathrm{st} \& \operatorname{dir}=\&$ occ $=$ first $\&$ part $=1 \& \mathrm{cid}=3822701$, accessed: 5.4 .2020 .
}

The Mayr ${ }^{8}$ case (ECJ C-506/06) presents relevance to the practice, which deals with the extraordinary situation of a laid-off worker while undergoing an "in vitro" fertilization protocol. After the court emphasized that Directive 92/85/ EC prohibited dismissal from the moment of the onset of the burden, namely in the instant case from the moment of implantation of fertilized eggs in the womb, it assessed that the protection of the employee could be relied on in Directive 76/207/ EEC of 9 February 1976 on the implementation of the principle of equal treatment for men and women as regards access to employment, vocational training, and working conditions if the court succeeds in proving that the dismissal was decided on account of the treatment received by the worker concerned to become pregnant.

Two other Directives, which do not constitute "Special Directives" within the meaning of Article 16 of Directive 89/391/EEC, also contribute specifically to the protection of certain groups of employees who are less protected: Temporary Workers - Directive 91/383/EEC, and Young Workers - Directive - 94/33/EC.

Two Framework Agreements have been added to these numerous Directives, the one of 8 October 2004 on Work Stress and the Framework Agreement on Harassment and Violence at Work of 26 April 2007, which may be considered as complementary directives to the general framework adopted in 1989 and are equivalent to the Special Directives.

As far as the legislative aspect is concerned, we can conclude that EU law pays a specific importance to this area, no doubt due to the constitutional traditions that the Union countries have built in advance, but their refinement has come underway by the unification of these rules - traditions within the Treaties, particularly the Directives as well as the ECJ Court decisions.

Naturally, workplace injuries and deaths are still present in these countries, but the protection of the rights of workers and their families is at the highest standard, not only legally defined but also implemented in practice.

\footnotetext{
${ }^{8}$ Accessible at: http://curia.europa.eu/juris/liste.jsf?language=en\&num=C-506/06, accessed: 26.3.2020.
} 


\section{National legislation in the field of Occupational Safety and Health}

The Republic of Kosovo is fully aware that our willingness and intention to join the European Union (EU) is not only a political and economic, but above all, a legal issue. Indeed the legal approximation process is the largest and most comprehensive task in the accession process. It represents one of the Copenhagen accession criteria to the European Union ${ }^{9}$.

Therefore, the Government of the Republic of Kosovo, aware of this very complex and challenging process, has been taking necessary measures and is committed to gradually align its legislation to become consistent with the one of the $\mathrm{EU}^{10}$.

Assessed in general terms, national legislation in the relevant field is built in the spirit of the ILO Conventions and in particular EU directives, but the main challenge remains the implementation of this legislation, therefore, the focus of the paper will be on the causes that are affecting regression in the practical sense.

As it is mentioned above, through the Stabilisation and Association Agreement (SAA) ${ }^{11}$ signed with the EU, Kosovo has taken legal obligation to approximate its national legislation with that of EU. More specifically, Article 82, foresees that:

"Kosovo shall progressively harmonise to that of the EU in the fields of working conditions notably on health and safety at work, and equal oppurtunities".

In the area of social policy and employment Kosovo has created a basic legal framework which regulates the areas of labour and employment, health and safety at work, the labour, inspectorate as well as forms of inclusion and social protection. Kosovo legislation regulating employment and social affairs policy is partially harmonised with the EU acquis and the main principles of EU law (Batalli, Vokrri, 2018).

\footnotetext{
${ }^{9}$ Accessible at: https://www.europarl.europa.eu/ftu/pdf/en/ FTU_5.5.1.pdf, accessed: 29.3.2020.

${ }^{10}$ Accessible at: http://mei-ks.net/repository/docs/practical_ guidelines_for_legal_aproximation.pdf, accessed: 28.3.2020.

${ }^{11}$ Accessible at: https://www.mei-ks.net/repository/ docs/20171027102511_kosovo-eu_saa_final_en.pdf, accessed: 27.3.2020.
}

In fact, a significant number of the directives from the "occupational safety and health" are specified in the applicable national legislation, starting with the basic law in the field of labor relations, Labor Law (No. 03/L-212), which sets out the Occupational Safety and Security and consequently the obligations that employers have in relation to employees to provide them with effective protection, then the protection of young people, women and persons with disabilities, pregnant women, maternity leave, and other aspects related to occupational safety.

Law on Occupational Safety and Health (Law no. $04 / \mathrm{L}-161)^{12}$ is a concrete protective mechanism in the legislative field and was drafted in accordance with international standards and with EU Framework Directive 89/391/ EEC, as well as a significant number of (transposed) regulations as part of secondary legislation. Part of the legislation in force that refer to the protection and safety of workers are also a) Law no. 03/L-017 On Amending and Supplementing the Law on Labor Inspectorate ${ }^{13}$, b) Law no. 04/L-125 on Health ${ }^{14}$, c) Law No. 04/L-249 on Health Insurance ${ }^{15}$ (not yet applicable), as well as other accompanying acts.

However, despite the "progress" in the legislative field, Kosovo has the main challenge in this segment. The phenomenon of deaths and injuries at the workplace has increased in recent years, and statistics ${ }^{16}$ of Labor Inspectorate show that only during 2018, 22 workers died at their workplace, particularly in the construction sector, and conditions are not favorable to workers at their workplace.

It was considered that with the adoption and entry into force of the Law on Occupational Safety and Health (Law no. 04/L-161), the relevant sphere would receive a well-deserved solution, but the reality on the ground proved quite the

\footnotetext{
${ }^{12}$ Accessible at: https://gzk.rks-gov.net/ActDetail.aspx?ActlD=8689 I, accessed: 27.3.2020.

${ }^{13}$ Accessible at: https://gzk.rks-gov.net/ActDetail. aspx?ActID=2581, accessed: 27.3.2020.

${ }^{14}$ Accessible at: https://gzk.rks-gov.net/ActDetail. aspx?ActID=8666, accessed: 27.3.2020.

${ }^{15}$ Accessible at: https://gzk.rks-gov.net/ActDetail. aspx?ActlD=9450, accessed: 28.3.2020.

${ }^{16}$ Accessible at: https://ip.rks-gov.net/wp-content/uploads/Raporti12-Mujor-2018-.pdf, accessed: 26. 10. 2020.
} 
opposite, and ironically, the situation has already worsened and regression is present in all areas where the issue of workers' safety and health at their workplace is related. Since the Law on Safety and Health came into force in 2013, after this period the number of injuries and fatal accidents of workers has been increased in comparison with previous years, for which arguments will be elaborated below.

In fact, the Law on Occupational Safety and Health, adopted in 2013, has been aligned with Council Directive 89/391/EEC of 12 June 1989 on the introduction of measures to encourage improvements in the safety and health of workers at work (Framework Directive). This law has paved the way for the transposition of the 19 individual directives emanating from this directive, addressing all issues referring to the protection and safety of workers in the workplace.

Key aspects referred to in the law relate to the prevention of occupational risks, the elimination of risk factors and accidents, information, consultation, balanced participation in improving the level of occupational safety and health, while the provisions of this law are implemented in the public, private and central sector as well as local government administration sector.

Furthermore, the law obliges the employer to create safe and healthy working conditions in all aspects of work, as well as the responsibility of the employer to cover all costs for the treatment of the employee who has suffered an injury at work or occupational disease.

More specifically, the employer (Articles 8 and 9) is obliged to inform and train employees on how to protect themselves against occupational hazards and how to use protective equipment. The employer should also appoint responsible persons within the personnel who are in charge for safety and health at work. Unlike EU countries, which require companies / corporations to set up Occupational Safety and Health Councils within their jurisdiction, but this is not required under the applicable legislation in Kosovo.

But how responsive employers are when delivering safe conditions for workers so that they can perform their duties without risking their lives and health? Unfortunately, very little and this is largely due to the reluctance of companies (their managers), to invest in modern work tools and at the same time they have not contributed for staff training, how and in what way to use these working tools.

Because of these shortcomings, whether due to the financial cost to employers for such protection and/or their negligence, the number of fatalities and injuries in the workplace is increasing steadily and at an alarming rate.

Institutionally wise, apart from political statements and attention-grabbing momentum, and this is usually the case when a worker dies, other than that, the issue of occupational safety, was not the primary objectives of the governments. The ongoing debate that the government will take measures to prevent deaths and injuries at workplace and that will strengthen the labor inspectorate and punish irresponsible employers is not producing concrete results.

In considerations of author the spectrum of work and the creation of conditions for decent work is of great importance and there is no better and lasting reflection to prove the stability within a state and its society. In this way, the state should consider strengthening the control mechanisms for the enforcement of workers' rights, particularly on working conditions and safety at work, including the construction sector, as one of the sectors where recently workers are dying and sustaining injuries at their workplace.

In order to continuously observe (monitor) the state of safety and health at work, as well as to develop adequate policies in this field, the Government of Kosovo, on the proposal of the Ministry of Labor and Social Welfare (MLSW), established the National Council for Occupational Safety and Health, which was never properly operationalized.

Knowing the importance of this area and the need for harmonization of national legislation with the Acquis, the Ministry of Labor and Social Welfare (MLSW), with the support of the European Union Office in Kosovo, launched the IPA 2014 Project (which was practically launched in 2016), and the primary objective was the transpo- 
sition of at least 10 individual Directives deriving from the Framework Directive (No. 89/391/EEC), listed as follows:

- Council Directive 89/656/EEC of 30 November 1989 on the minimum health and safety requirements for the use by workers of personal protective equipment at the workplace (third individual directive within the meaning of Article 16 (1) of Directive 89/391/EEC).

- Council Directive 90/269/EEC of 29 May 1990 on the minimum health and safety requirements for the manual handling of loads where there is a risk particularly of back injury to workers (fourth individual Directive within the meaning of Article 16 (1) of Directive 89/391/EEC).

- Council Directive 90/270/EEC of 29 May 1990 on the minimum safety and health requirements for work with display screen equipment (fifth individual Directive within the meaning of Article 16 (1) of Directive 89/391/EEC).

- Council Directive 92/58/EEC of 24 June 1992 on the minimum requirements for the provision of safety and/or health signs at work (ninth individual Directive within the meaning of Article 16 (1) of Directive 89/391/EEC).

- Council Directive 92/91/EEC of 3 November 1992 concerning the minimum requirements for improving the safety and health protection of workers in the mineralextracting industries through drilling (eleventh individual Directive within the meaning of Article 16 (1) of Directive 89/391/ EEC).

- Council Directive 92/104/EEC of 3 December 1992 on the minimum requirements for improving the safety and health protection of workers in surface and underground mineral-extracting industries (twelfth individual Directive within the meaning of Article 16 (1) of Directive 89/391/EEC).

- Directive 1999/92/EC of the European Parliament and of the Council of 16 Decem- ber 1999 on minimum requirements for improving the safety and health protection of workers potentially at risk from explosive atmospheres (15th individual Directive within the meaning of Article 16(1) of Directive 89/391/EEC).

- Directive 2002/44/EC of the European Parliament and of the Council of 25 June 2002 on the minimum health and safety requirements regarding the exposure of workers to the risks arising from physical agents (vibration) (sixteenth individual Directive within the meaning of Article 16(1) of Directive 89/391/EEC).

- Directive 2003/10/EC of the European Parliament and of the Council of 6 February 2003 on the minimum health and safety requirements regarding the exposure of workers to the risks arising from physical agents (noise) 2007/30/EC.

- Directive 2009/148/EC of the European Parliament and of the Council of $30 \mathrm{No}-$ vember 2009 on the protection of workers from the risks related to exposure to asbestos at work.

At the same time, in addition to extending the practical implementation of the relevant directives (as above), Kosovo institutions should continue to supplement the legal framework in this area in which eleven (11) other directives have been identified, which should be transposed into national legislation to complete the legislative aspect of the relevant area in line with EU recommendations (NPISAA, 2016).

Lastly, during the 2019 the Ministry of Labour and Social Welfare has adopted the Draft-law on Maternity and Parental Leave and on 2020 Adoption of two (2) Regulations: Regulation $(01 / 2020)^{17}$ on Amendment on Suplement of the Regulation 04/2014 on Minimum Safety and Health Requirements for the Workplace; and Regulation (02/2020) on Amandment on Suplement of the Regulation 05/2014 on Minimum Safety and He-

\footnotetext{
${ }^{17}$ Accessible at: https://mpms.rks-gov.net/linqe/legjislacioni/?cp_ primar=2, accessed: 3.11 .2020 .
} 
alth Requirements for the use of Work Equipment by Workers at Workplace. At the same time has adopted the Concept Paper on the advancement of legislation in the area of occupational safety and health; and on Increase in the number of inspectors $^{18}$.

\section{CHALLENGES ON THE PRACTICAL IMPLEMENTATION OF THE LEGISLATION}

Kosovo aspires to join the EU and a condition for successful accession is the transposition and enforcement of the EU Acquis in the Kosovo legal system before the date of membership.

It should be emphasized in advance that Kosovo has a relatively adequate legal framework that addresses issues in the field of work and protection of employee rights, but the implementation of applicable legislation in practice remains a real challenge. In this regard, the level of protection or respect for workers' rights is not at all satisfactory in the private sector.

The main disadvantages that distinguish the private sector are that a significant portion of employees in this sector are part of the informal economy working without contracts and with extended working hours, especially in the construction sector during the summer season, without protective equipment and at high temperatures, some of which do not enjoy sufficient daily break/leave and, worse, weekly and annual leave (rights which are sanctioned in EU Directives), are not entitled to compensated overtime work, lack of basic working conditions and therefore the risk of injury and fatality is permanently present.

A common feature of deficiencies in both sectors (public and private) is the lack of compulsory health insurance, a fact that makes employees not comfortable in performing their daily duties.

The issue of Occupational Safety and Health remains the crucial challenge of implementing re-

\footnotetext{
${ }^{18}$ Accessible at: http://mei-ks.net/repository/docs/raport_mbi_ zbatimin_e_pkzmsa_gjate_vitit_2019_eng.PDF, accessed: 24.3.2020.
}

levant legislation. As noted above, the spectrum of workers' rights that refer to occupational safety and health, in addition to primary legislation, has been sufficiently addressed by secondary legislation, where a considerable number of Regulations ${ }^{19}$ have been adopted which are in accordance with the EU Framework Directive [89/391 EEC], respectively Article 16 of this Directive.

The whole illustration process of secondary legislation is intended to argue that even though the legal sanction in this area is well defined and in line with EU Directives, in particular with Regulations (No. 04/2014 and No. 05/2014) with Directive 89/654/EEC respectively Directive 2009/104/ $\mathrm{EC}$, but when the implementation of that legislation is lacking, then the final result can never be satisfactory.

Thus, only legal determination (on paper), without enforcement, turns out to be a fraud for workers. Therefore, due to inadequate and unsafe working conditions, the number of deaths and injuries in the workplace continues to increase each calendar year. Paradoxically, the number of deaths and injuries of workers in the workplace in Kosovo was lower before the two basic laws began to be in force: Labor Law (03/L-212) and Law on Safety and Health at Work (04/L-161).

While in 2011, the number of injuries at work was 42 and number of deaths was 10, in subsequent years, this number has only continued to increase, even though the legal sanctions and their protection (after 2010) were much higher and much more protected than in previous years. Thus, according to the reports of the Labor Inspectorate and the Statistical Office of Kosovo, in 2012 there were 52 accidents with injuries in the workplace and 12 deaths, while in 2013, there were 47 serious injuries and 17 deaths recor$\operatorname{ded}^{20}$, which were reflected also to the study of Kosovo Foundation for Open Society's "Employee Rights (Legal Framework), Safety at Work and Implementation Mechanism (Input for the Progress Report 2014) ${ }^{21}$.

\footnotetext{
${ }^{19}$ Accessible at: https://ip.rks-gov.net/?page_id=2554 accessed: 26.3.2020.

${ }^{20}$ Accessible at: https://ask.rks-gov.net/media/1378/statistics-ofdeaths-2013.pdf p. 33, accessed: 9.11.2020.

${ }^{21}$ Accessible at: http://www.civilsocietylibrary.org/CSL/2468/ Employee-Rights-Legal-Framework-Safety-at-work-andImplementation-Mechanisms, p. 14, accessed: 27.10. 2020.
} 
In the years that followed, the trend of workplace injuries and deaths continued to be high. This undoubtedly represents a legitimate concern and at the same time uncertainty for workers. Based on the analysis of these facts, the question naturally arises as to the role of the Labor Inspectorate in exercising its competence authorized by the Assembly of Kosovo through Law no. 03/L017 and secondary legislation to oversee the implementation of legislation referring to employee rights.

The factual reality has proved that this administrative authority could not even play its part closely. This is due to many factors, some related to the work and efficiency of the Inspectors themselves, as well as the lack of political and institutional willingness to increase human resources, where for instance only 49 Labor Inspectors operate throughout the territory of Kosovo.

The limited capacities of the Labor Inspectorate were highlighted in most of the European Commission's progress reports ${ }^{22}$, and these shortages are directly affecting their work, therefore even in the best scenario within one calendar year, out of the total number of businesses operating in Kosovo, only 17 percent of these businesses have managed to be inspected by Inspectors. Contrary to the constant demands of public opinion, civil society, trade unions and other relevant stakeholders for increasing the number of inspectors and at the same time appeals for a functioning cabinet with fewer human resources, it just happened the opposite, when the previous government appointed 80 deputy Ministers.

As a result of these factors, the issue of occupational safety (not just in the construction sector) remains a concern. Another untreated aspect is also the issue of occupational safety of pregnant women, who have varying sensitivity to high temperatures, long standing for a long time, which for men of the same age and position will not pose a risk, but that the Law on Occupational Health and Safety does not specifically address the relevant issues.

${ }^{22}$ Accessible at: https://ec.europa.eu/neighbourhood-enlargement/ sites/near/files/20180417-kosovo-report.pdf p. 59., accessed: 27.10.2020.
While occupational safety issues (referred to above) for pregnant women have not been addressed, on the other hand the Labor Law regarding maternity leave is highly influential and provides that maternity leave can enjoy a long-term leave (up to a year).

The timing of this break was undoubtedly positive, and this came as a result of a public debate and good coordination between social partners, civil society and professionals in the field, but the reality in practice has had negative consequences for its implementation, and this occurred particularly in the private sector.

This occurred because most employers in the private sector, as a result of the one (1) year leave duration and the obligation to pay their maternity benefits at a rate of 70 percent of basic salary for a period of six (6) months, began to reduce drastically the number of women hired, while most of those who went on maternity leave, their contracts were terminated and replaced with new staff, or were not covered by legally paid salaries during their maternity leave.

It is thus confirmed by the statistics of the relevant Agencies, presented by RIINVEST Institute on the study "Women in the Workforce" (An analyzes of the Workforce Conditions for Women in Kosovo $)^{23}$ which show that since the adoption of the Labor Law (2010), the number of employed women in the private sector has been steadily declining, and this reality runs counter to the basic principles of European labor law, including "equality between men and women" in the employment sector.

The analogy used in "women's safety at work" and "maternity leave" lies in the fact that while in the area of safety at work, there were no specific references for sensitive or hazardous jobs that they (women) protect, whilst regarding the maternity leave, there are clearly legal provisions guaranteeing their respective leave, but the practical aspect is not in the proper proportion. Consequently, requests have been made to reduce the du-

\footnotetext{
${ }^{23}$ Accessible at: https://www.riinvestinstitute.org/uploads/ files/2017/November/10/Women_in_the_workforce1510308291.pdf p. 17, accessed: 28.10.2020.
} 
ration of the relevant (maternity) leave, or to limit or reduce the employer's financial burden during this period.

Another worrying aspect is that of the application of norms by employers in the private sector on matters relating to the termination of a previously agreed contract ${ }^{24}$ of free will between the two parties (employers and employees). Practice has shown that in many cases employers have terminated contracts with employees without any prior notice and by failing to comply with the time limits provided in the legislation (fixed-term contracts) and without any valid reason.

Law on Labor No. 03/L-212 ${ }^{25}$ through article 71 (paragraph 2) specifies that "The employer may terminate an employment contract for a fixed term with thirty (30) calendar days notice. The employer who does not intend to renew a fixed term contract must inform the employee at least thirty (30) days before the expiry of the contract. Failure to do so entitles the employee to an extension of employment with full pay for thirty (30) calendar days". As to the reasons, Article 72 provides that "The decision to terminate an employment shall be issued in writing and shall include the grounds for the dismissal". Such actions have created a legal uncertainty for workers and an inconvenience in their work.

The system remains challenged by the issue of implementation of the Law on Health Insurance (04/L-249), adopted by the Kosovo Assembly on 10 April 2014. The uncertainty about health premiums and the way they are collected, as well as other aspects of the organizational nature and financial cost of implementing the law, have led governments to sometimes proclaim starting the implementation of the respective law and then withdrawing or postponing it for another period, but in reality, it never came to completion (not until now).

Certainly, the lack of compulsory health insurance and other basic social security insurance greatly undermines the prospects for sustainable and compatible employment with international

\footnotetext{
${ }^{24}$ Accesible at: http://iksweb.org/en/wp-content/uploads/2018/12 Silent-Deaths.pdf p. 11. accessed: 9.11.2020

25 Accessible: https://gzk.rks-gov.net/ActDetail.aspx?ActID=2735, accessed: 4.11.2020.
}

standards. Without a health insurance and in this line, without adequate protection of workers in their workplace, there can be no talk of progress in the field. Let's recall the cases of workplace injuries and deaths, most of them did not enjoy the right to this insurance, which would of course be some legitimate moral and financial support for their families.

Author thinks that reflecting the reality regarding the relevant field was more than necessary, to prove that just writing on paper is not enough without the practical application of legislation. When all of this is compounded by the lack of proper union organization, then the question arises as to who more than their representatives, the employees should trust.

\section{CONCLUSION}

From the research of this work paper, we noted that the rights of labor including of safety and health at work, and relations arising from it, represent one of the fundamental rights guaranteed in the Charter of Fundamental Rights of the European Union, legal acts on the establishment of the European Union, respectively the right of European labor law and fundamental acts (Constitutions) of most countries of the $\mathrm{EU}$, including the Constitution of the Republic of Kosovo.

As it is outlined above the national interest strategic goal of the Government of Kosovo is to fulfill the conditions for full membership in the European Union. The approximation of the Kosovo legislation with EU Acquis is one of the prerequisites for Kosovo to adhere to the European Union.

Our daily basis routine has brought to our attention numerous complaints of workers in the area of labor relations, particularly on the area of safety and health at work, for lack of labor law as well as non-implementation, so we consider that necessary steps towards these reasonable requirements should be taken.

It is fact that the adoption of Labor Law and the Law on Safety and Health were regulated the issues of employment to a certain degree; however, their high financial costs remain a challenge. 
The practice showed that the implementations of these laws are not satisfactory with safety and health at work, maternity leave, and other relevant areas.

Having in consideration the overview of the current state of the occupational safety and health spectrum and the need for future progress, I consider to be taken the actions, as below:

- To finalize the process of amending the Labor Law in order to harmonize it with EU Law;

- Take the necessary measures to implement the legislation on safety at work, as a consequence of the obligations arising from the Acquis, and complete the remainder of the legal framework;

- To adopt the new Law on the Labor Inspectorate and to include additional powers in supervision and penalties against employers;

- To strengthen the human and infrastructure capacities of the Labor Inspectorate, including to increase the salaries for them;

- To be advocated by parliamentary parties and the government's commitment to the adoption of the Special Law on Nursing Mothers;

- Determine the list of occupational diseases resulting from the employment relationship;

- To functionalize the National Council for Occupational Safety;

- Pay particular attention to new forms of work-related illnesses, especially stress and psychological problems that are present in all categories of work types;

- To start the implementation of the Law on Health Insurance as a strong guarantee for life and health;

- To work intensively on enabling and certifying those responsible with occupational safety;

- Increase cooperation between social parthers (Government, employers and trade unions) in addressing these issues in a merit way.
These and other issues elaborated above represent the main basis for the implementation of current legislation, the proper functioning of the relevant institutions, in terms of improving working conditions and the safety of workers' health.

\section{LITERATURE}

Arthurs, H.: The Idea of Labour Law, Oxford University Press Inc., New York, 2011.

Brunstein, A.: International and Comperative Labour Law, Current challengies, International Labour Office, Geneva, 2009.

Bercusson, B.: European Labour Law (Law in Context), Cambridge University Press, New York, 2009.

Beverly, A.: Searle, Well - Being, In search for a good life, Policy Press, Bristol, UK, 2008.

Hennion, S., Le Barbier-Le Bris, M., Del Sol, M.: Le droit social europeen et international, Dalloz et Sirey, Paris, 2010.

B. de Witte, "Legal Instruments and the LawMaking in the Lisbon Treaty", S. Griller, J. Ziller, (eds.), "The Lisbon Treaty: EU Constitutionalism without a constitutional Treaty?", 2008 Springer Verlag Wien, 92.

Batalli, M., Vokrri, M.: Harmonisation of Kosovo labour legislation with that of EU, SEER Journal for Labour and Social Affairs in Eastern Europe, $21,2018,1,67-82$.

Lowisch, M.: Labor Law in Europe, Ritsuimekan Law Review, 20, 2003, $101-115$.

ILO Standards: related activities in the area of occupational safety and health: An in- depth stu$d y$ for discussion with a view to the elaboration of a plan of action for such activities. Report VI, Geneva, International Labour Office, 2003, 1.

ILO: Safety and Health at the Heart of the Future of Work "Building of 100 years of experience". ILO Office, 2019, 3.

The EU Charter of Fundamental Rights: From Declaration to Binding Instrument (Ius Gentium: Comparative Perspectives on Law and Justice), 
Editor: Giacomo Di Federico, Springer; 1st Edition, 2010, $166-167$.

Kosovo Foundation for Open Society's project (KFOS): Employee Rights (Legal Framework), Safety at Work and Implementation Mechanisms (Input for the Progress Report 2014).

RIINVEST Institute - Women in the Workforce: (An Analyses of the Workforces Conditions for Women in Kosovo), 2017.

\section{Kosovar Stability Initiative: Silent Deaths, 2018.}

\section{Legal sources:}

Council Directive No. 89/391/EEC of 12th June 1989 on the introduction of measures to encourage improvements in the safety and health of workers at work.

Council Directive 89/656/EEC of 30th November 1989 on the minimum health and safety requirements for the use by workers of personal protective equipment at the workplace.

Council Directive 90/269/EEC of 29th May 1990 on the minimum health and safety requirements for the manual handling of loads where there is a risk particularly of back injury to workers.

Council Directive 90/270/EEC of 29th May 1990 on the minimum safety and health requirements for work with display screen equipment.

Council Directive 92/58/EEC of 24th June 1992 on the minimum requirements for the provision of safety and/or health signs at work.

Council Directive 92/91/EEC of 3rd November 1992 concerning the minimum requirements for improving the safety and health protection of workers in the mineral- extracting industries through drilling.

Council Directive 92/104/EEC of 3rd December 1992 on the minimum requirements for improving the safety and health protection of workers in surface and underground mineralextracting industries.
Council Directive and of the EU Parliament 1999/92/EC of 16th December 1999 on minimum requirements for improving the safety and health protection of workers potentially at risk from explosive atmospheres.

Council Directive and of the EU Parliament 2002/44/EC of 25th June 2002 on the minimum health and safety requirements regarding the exposure of workers to the risks arising from physical agents (vibrations).

Council Directive and of the EU Parliament 2003/10/EC of 6th February 2003 on the minimum health and safety requirements regarding the exposure of workers to the risks arising from physical agents (noise) 2007/30/EC.

Council Directive and of the EU Parliament 2009/148/EC of 30th November 2009 on the protection of workers from the risks related to exposure to asbestos at work.

Council Directive 91/383/EEC of 25th June 1991 on supplementing to encourage improvements in the safety and health at workers with a fixed-duration employment relationship or a temporary employment relationship.

Council Directive 94/33/EC of 22nd June 1994 on the protection of young people at work.

Council Directive 76/207/EEC of 9th February 1976 on the implementation of the principle of equal treatment for men and women as regards access to employment, vocational training, and working conditions.

Law on Labour of the Republic of Kosovo, No. 03/L-212. 2010.

Law on Occupational Safety and Health, No. 04/L-161. 2013.

Law on Health, No. 04 / L-125. 2013.

Law on Health Insurance, No.04/L-249. 2014.

Law on amending and suplementing the Law on Labour Inspectoriate, No. 03/L-017. 2008.

National Programme for Implementation of the Stabilisation and Association Agreement (NPISSA). 2016. 


\section{Case Law:}

ECJ case C-226/06, Comission/France, 5 June 2008. - Judgment of the Court (First Chamber). Failure of a Member State (French Republic) to fulfil the obligation - Directive 89/391/EEC - Mesures to encourage improvements in the safety and health of workers at work - Articles 2, 10 (1) and 12 (3) and (4) - Defective transposition.

ECJ Kiisski case C- 116/06, 20 September 2007.- Judgment of the Court (Fourth Chamber) Sari Kiisky v Tampereen Kaupunki (Finland). Equal treatment for men and women - Protection of pregnant employees - Article 2 of Directive 76/207/EEC - Right to maternity leave - Article 11 of Directive 92/85/EEC - Effect on the right to obtain an alteration of the duration of "child leave"

ECJ Paquay case C-460/06, 11 October 2007.Judgment of the Court (Third Chamber). Nadine Paquay $v$ Societe d'architectes Hoet + Minne SPRL. Reference for a preliminary ruling: Tribunal du travail de Bruxelles - Belgium. Social Policy Protection of pregnant women - Directive 92/85/ EEC - Article 10 - Prohibition on dismissal from the beginning pregnancy to the end of maternity leave - Period protection - Decision to dismiss a female worker during that period of protection. Notification and implemetation of the decision to dismiss after the expiry of that period - Equal treatment for male and female workers - Directive 76/207/EEC - Articles 2(1), 5(1), and 6. Direct discrimination on grounds of sex - Sanctions.

ECJ Mayr case C-506/06, 26 February 2008. Judgment of the Court (Grand Chamber). Sabine Mayr v Backerei und Konditorie Gerhard Flockner OHG (Austria). Social Policy - Directive 92/85/ EEC - Measures to encourage improvements in the safety and health at work pf pregnant workers and workers who have recently given birth or are breastfeeding - Meaning of "pregnant worker". Prohibition of dismissal of pregnant workers during the period from the beginning of their pregnancy to the end of the maternity leave. Woman dismissed where, at the date she was given notice of her dismissal, had been in vitro, but not yet transferred to her uterus - Directive 76/207/EEC - Equal treatment for men and women - Women undergoing in vitro fertilisation treatment - Prohibition of dismissal - Scope. 


\section{ASPEKTI SIGURNOSTI I ZDRAVLJA NA RADU U} KONTEKSTU EU-a I KOSOVA

SAŽETAK: Sigurnost i zdravlje na radu dvije su ključne komponente učinkovitosti zaposlenika na njihovom radnom mjestu, a istovremeno im jamče da mogu izravno utjecati na dobrobit i produktivnost zaposlenika, kao i na njihovu zaradu. Očito je da zakonska definicija i njihova zaštita pripadaju državnom resoru, odnosno institucijama koje su ovlaštene nadzirati provedbu zakona kod poslodavaca. Uzimajući u obzir činjenice kako izvještaji dobiveni iz područja rada, posebno "Sigurnost i zdravlje na radu", odgovaraju svakodnevnom životu većine građana, razumljivo je zašto postoji potreba za odgovarajućim zakonskim propisima u ovom području na nacionalnoj i međunarodnoj razini, uključujući međunarodne standarde (ILO konvencije Međunarodne organizacije rada), kao i Ugovore - EU direktive koje se odnose na relevantno područje. U tom kontekstu pokušalo se objasniti prirodu i značaj ove dvije komponente na međunarodnoj razini, kao i razmišljanje koje imaju u nacionalnom zakonodavstvu, posebno u slučaju Kosova u vezi s konvencijama ILO i s pravom EU-a, posebno Okvirna direktiva EZ br. 89/391 od 12. lipnja 1989. godine. Razlozi za takvu razradu nalaze se u činjenici težnje našeg društva da bude dio Europske unije, te razvoju odgovarajućeg zakonodavstva u ovom polju, kao i kompatibilnog s pravom EU-a, posebno nakon potpisivanja Sporazuma o stabilizaciji i pridruživanju (SSP) između Kosova i Europske unije gdje je praktično Kosovo preuzelo pravnu i ugovornu obvezu približavanja nacionalnog zakonodavstva pravnoj stečevini EU-a. Izazovi u provedbi nacionalnog zakonodavstva, kao i sve veći broj smrtnih slučajeva i ozljeda na radnom mjestu bit će glavni fokus ovog članka. U tom će se kontekstu analizirati i proučavati metode za praktično usklađivanje, kao i preporuke o postupanju u određenim područjima kako bi se radnicima zajamčilo dostojanstvo i prije svega sigurnost i zdravlje na njihovom radnom mjestu.

Ključne riječi: zaštita i zdravlje na radu, Europsko pravo, Sporazum o stabilizaciji i pridruživanju (SSP) između Kosova i EU-a, direktive, inspekcija rada 